\title{
Urban air pollution and emergency admissions for asthma in four European cities: the APHEA Project
}

\author{
J Sunyer, C Spix, P Quénel, A Ponce-de-León, A Pönka, T Barumandzadeh, \\ G Touloumi, L Bacharova, B Wojtyniak, J Vonk, L Bisanti, J Schwartz, \\ K Katsouyanni
}

\begin{abstract}
Background - A study was undertaken to assess the combined association between urban air pollution and emergency admissions for asthma during the years 1986-92 in Barcelona, Helsinki, Paris and London.

Methods - Daily counts were made of asthma admissions and visits to the emergency room in adults (age range 15-64 years) and children ( $<15$ years). Covariates were short term fluctuations in temperature and humidity, viral epidemics, day of the week effects, and seasonal and secular trends. Estimates from all the cities were obtained for the entire period and separately by warm or cold seasons using Poisson time-series regression models. Combined associations were estimated using meta-analysis techniques.

Results - Daily admissions for asthma in adults increased significantly with increasing ambient levels of nitrogen dioxide $\left(\mathrm{NO}_{2}\right)$ (relative risk (RR) per $50 \mu \mathrm{g} / \mathrm{m}^{3}$ increase $1.029,95 \%$ CI 1.003 to 1.055 ) and non-significantly with particles measured as black smoke (RR 1.021, 95\% CI 0.985 to 1.059). The association between asthma admissions and ozone $\left(\mathrm{O}_{3}\right)$ was heterogeneous among cities. In children, daily admissions increased significantly with sulphur dioxide $\left(\mathrm{SO}_{2}\right)$ (RR 1.075, 95\% CI 1.026 to 1.126 ) and non-significantly with black smoke (RR 1.030, 95\% CI 0.979 to 1.084) and $\mathrm{NO}_{2}$, though the latter only in cold seasons (RR $1.080,95 \%$ CI 1.025 to 1.140). No association was observed for $\mathrm{O}_{3}$. The associations between asthma admissions and $\mathrm{NO}_{2}$ in adults and $\mathrm{SO}_{2}$ in children were independent of black smoke. Conclusions - The evidence of an association between air pollution at current urban levels and emergency room visits for asthma has been extended to Europe. In addition to particles, $\mathrm{NO}_{2}$ and $\mathrm{SO}_{2}-$ by themselves or as a constituent of a pollution mixture - may be important in asthma exacerbations in European cities. (Thorax 1997;52:760-765)
\end{abstract}

Keywords: asthma, air pollution, hospital admissions, Europe.
Asthma morbidity has been increasing for reasons not yet well understood. ${ }^{1}$ Although evidence for an increasing incidence of asthma due to air pollution has not been provided, air pollution could exacerbate existing asthma. ${ }^{2}$ In asthmatic volunteers, controlled exposures to sulphur dioxide $\left(\mathrm{SO}_{2}\right)$, ozone $\left(\mathrm{O}_{3}\right)$, and nitrogen dioxide $\left(\mathrm{NO}_{2}\right)$ at levels compatible with urban life produced bronchial hyperresponsiveness and inflammation and reduced the dose of aeroallergen needed to produce a given bronchial response. ${ }^{3-9}$ Studies on air pollution in laboratory face two main limitations: the non-representative selection of subjects and the simplification of human exposures.

Some recent population studies have related daily levels of particles and ozone to the increase of emergency room admissions for asthma, though these findings do not extend to all the studies. ${ }^{210}$ Epidemiological studies on daily variations in asthma admissions and air pollution levels assess the general population at real world exposures with adequate internal validity. ${ }^{112}$ The APHEA Project ${ }^{13}$ is an international European prospective standardised study on the short term health effects of air pollution in the general population. This paper combines the individual city associations of air pollution with asthma admissions in Barcelona, Helsinki, London and Paris, the four European cities in APHEA that collected data on asthma. This multi-city study allows an evaluation of a wide variability in environmental exposures and enhances the external validity of findings. Individual results have been reported for Helsinki ${ }^{14}$ and Barcelona. ${ }^{15}$

\section{Methods}

The number of asthma admissions on each day, occurring during the years shown in table 1 , were totalled for each centre as reported elsewhere. ${ }^{14-18}$ Daily counts of asthma admissions - that is, any attendance with the ICD-9 code 493 - were made for children $(<15$ years) and adults (15-64 years). The age groups were divided because the diagnostic category asthma in children may include syndromes of a different nature from those in adults. ${ }^{19}$ An age of 15 years was the cut-off point as it 
divides paediatric from adult wards. The outcome variable was not strictly the same among the cities: emergency room visits in Barcelona, emergency hospital admissions in London and Helsinki, and total admissions in Paris. Data were provided by governmental or municipal registers, except for Barcelona where the register is part of ongoing studies. The admissions covered all hospitals in each city which admit medical emergencies, except for Barcelona where participating hospitals cover $90 \%$ of emergencies. Completeness of diagnostic data in the registers was over $90 \%$ in all cities except in London where it rose from $73 \%$ to $95 \%$ during the study period.

Air pollution exposure was measured at the city monitoring stations which provide an average for the entire city. Details of the monitoring sites, measurement methods, and indicators can be found elsewhere. ${ }^{14171820}$ Briefly, Barcelona and London had small networks in the city centre covering street-type pollution - three and four stations, respectively, though in London only one measured $\mathrm{O}_{3}$ and two $\mathrm{NO}_{2}$. In Paris there were four stations covering background type pollution (three of which were in the suburbs) and in Helsinki the network monitored both types of pollution (eight stations, half in suburbs). Hourly and daily averages were obtained for $\mathrm{SO}_{2}, \mathrm{NO}_{2}$, and $\mathrm{O}_{3}$ and eight-hour averages for $\mathrm{O}_{3}$. Particulate matter, also called black smoke, was assessed by reflectometry. Missing values at each station site, ranging from $5 \%$ to $20 \%$, were replaced using the available measurements from the other monitoring sites following a common procedure. ${ }^{21}$ There was no quality control programme within APHEA to ensure comparability of air pollution measurements, though all countries conform to EU requirements. ${ }^{21}$

Covariates were risk factors for attendance for asthma that vary on a day to day basis, possibly in association with air pollution, such as short term fluctuations in weather. Among the routine meteorological data, humidity and temperature were the indicators selected based on previous epidemiological evidence. ${ }^{13}$ Data on influenza epidemics provided by epidemiological surveillance services were available in Barcelona and Paris. ${ }^{1820}$ In London daily admissions for influenza were used. ${ }^{17}$ Soybean epidemics were controlled for in Barcelona. ${ }^{16}$

All the centres kept to a strict procedure in the analysis agreed in advance by the APHEA group to ensure the maximum degree of comparability. ${ }^{2122}$ Poisson time series regression models were built up in each centre to exclude the long wavelength patterns, seasonal patterns, day of the week effects, and the in- fluences of weather, epidemics and autocorrelation. The proper control of temperature and humidity was considered critical, and centre-specific models were developed. Most centres fitted a quadratic function of temperature (and humidity) and, in addition, included dummy variables defining hot and humid days. In Paris a linear function was selected after checking the data using spline functions. Pollutants were included in the model at the last step. The adjusted relative risk (RR) of daily asthma admissions per $50 \mu \mathrm{g} /$ $\mathrm{m}^{3}$ of increase in air pollution was estimated. $\mathrm{RR}$ allows comparability of the association between centres of different sizes. Each centre determined for each pollutant a best fitting one-day result from either the same day or one of the three preceding days, and a best fitting cumulative result corresponding to the mean of the same day and the previous day, the same day and the two previous days, or the same day and the three previous days. The selection of the most sensitive lag day per centre was done because a delay can be influenced by local factors such as wind direction, size of the city, or location of the monitoring sites. ${ }^{21}$ To simplify the meta-analysis each centre fitted a linear relationship between the pollutant and asthma admissions for days below $200 \mu \mathrm{g} / \mathrm{m}^{3}$. Separate regressions were fitted for the whole period, for the period in which heating was used (October to March), and for the warm period (April to September).

A combined estimate across cities was computed by taking the weighted average of the city-specific coefficients using inverse variance weights - that is, fixed effects model. ${ }^{2122} \mathrm{~A} \chi^{2}$ test for homogeneity of coefficients was performed. If heterogeneity was present $(p<0.20)$, a random effects model was also estimated, the weights incorporating the between cities variance and the within cities variances. Only analyses for $\mathrm{O}_{3}$ required a random effects model. $^{23}$

\section{Results}

Table 1 presents a description of the daily number of asthma admissions in Helsinki, London, and Paris, and asthma emergency room visits for Barcelona. Daily numbers varied considerably from London to Helsinki, with London having the greatest weight in the joint analysis and Helsinki the lowest. Air pollution also varied between the cities (table 1). Although data were not strictly comparable because of local network characteristics, Barcelona had the highest levels for all the pollutants except $\mathrm{NO}_{2}$ and Helsinki the lowest. Particle levels varied widely from London to Barcelona.

Table 1 Cities and descriptive daily values

\begin{tabular}{|c|c|c|c|c|c|c|c|}
\hline \multirow[t]{2}{*}{ City } & \multirow[t]{2}{*}{ Period } & \multicolumn{2}{|c|}{ Asthma admissions $^{1}$} & \multicolumn{4}{|c|}{ Median (range) of air pollutants ${ }^{2}\left(\mu \mathrm{g} / \mathrm{m}^{3}\right)$} \\
\hline & & $\leq 14$ years & 15-64 years & Sulphur dioxide & Black smoke & Nitrogen dioxide & Ozone \\
\hline & & - & 3.9 & & $40(11-258)$ & & \\
\hline & & $\begin{array}{l}0.9 \\
19.8\end{array}$ & $\begin{array}{l}0.7 \\
13.1\end{array}$ & $\begin{array}{l}16(3-95) \\
31(9-100)\end{array}$ & & $\begin{array}{l}35(9-78) \\
69(27-347)\end{array}$ & $\begin{array}{l}27(1-78) \\
40(1-188)\end{array}$ \\
\hline $\begin{array}{l}\text { Laris } \\
\text { Pan }\end{array}$ & $1987-92$ & $\begin{array}{l}1.0 \\
4.6\end{array}$ & 7.3 & $23(1-219)$ & $28(4-186)$ & $42(12-157)$ & $36(1-230)$ \\
\hline
\end{tabular}

${ }^{1}$ Average of daily number of hospital admissions, except for Barcelona where emergency room visits were measured.

24 hour average values for $\mathrm{SO}_{2}$, black smoke, and $\mathrm{NO}_{2}$, and one hour maximum value for $\mathrm{O}_{3}$. 
Table 2 Adjusted $\dagger$ relative risk of asthma admissions for subjects aged 15-64 per $50 \mu \mathrm{g} / \mathrm{m}^{3}$ increase in air pollutants (and lag) $^{12}$

\begin{tabular}{|c|c|c|c|c|c|}
\hline Air pollutant & Barcelona & Helsinki & London & Paris & Total $(95 \%$ CI) \\
\hline \multicolumn{6}{|l|}{ Sulphur dioxide } \\
\hline $24 \mathrm{~h}$ average & $0.968(3)$ & $1.365(2)$ & $0.968(2)$ & $1.012(2)$ & $0.997(0.961$ to 1.034$)$ \\
\hline Cumulative & 0.999 (3) & $1.647(3)$ & $0.971(2)$ & 1.007 (3) & $1.003(0.959$ to 1.050$)$ \\
\hline \multicolumn{6}{|l|}{ Black smoke } \\
\hline $24 \mathrm{~h}$ average & $1.036(3)$ & - & $1.035(0)$ & $1.012(0)$ & $1.021(0.985$ to 1.059$)$ \\
\hline Cumulative & $1.027(3)$ & - & $1.026(1)$ & $1.032(3)$ & $1.030(0.981$ to 1.081$)$ \\
\hline \multicolumn{6}{|l|}{ Nitrogen dioxide } \\
\hline Hourly maximum & $1.023(0)$ & $1.065(0)$ & $1.008(0)$ & $1.017(0)$ & $1.012(0.999$ to 1.024$)$ \\
\hline $24 \mathrm{~h}$ average & $1.048(0)$ & $0.900(1)$ & $1.024(0)$ & 1.041 (1) & $1.029(1.003$ to 1.055$) *$ \\
\hline Cumulative & $1.087(3)$ & $0.905(1)$ & $1.025(1)$ & $1.078 *(1)$ & $1.038(1.008 \text { to } 1.068)^{*}$ \\
\hline \multicolumn{6}{|l|}{ Ozone } \\
\hline Hourly maximum & $1.048 *(0)$ & $0.779(0)$ & $1.071 *(1)$ & $0.937(1)$ & $1.015(0.955$ to 1.078$)$ \\
\hline 8 hour maximum & $1.058(0)$ & $1.183(2)$ & $1.086 *(1)$ & $0.986(1)$ & $1.035(0.937$ to 1.144$)$ \\
\hline
\end{tabular}

${ }^{1}$ Single day lag: effects may be on the same day (0) or lagged up to three days (3).

${ }^{2}$ Cumulative: effects of mean of same day and up to three previous days.

$* \mathrm{p}<0.025$.

† Adjusted for trend, seasonality, day of the week, temperature, humidity, and influenza epidemics.

In adults asthma admissions were positively associated with black smoke, $\mathrm{NO}_{2}$, and $\mathrm{O}_{3}$, although the associations with black smoke and $\mathrm{O}_{3}$ were not statistically significant (table 2). For black smoke a positive though non-statistically significant association was observed in all cities. The association with cumulative exposure was lower than one day association in some cities. Restriction to lag 0 in all cities resulted in a very similar association (RR 1.020, $95 \%$ CI 0.983 to 1.057 ), but the combined effect for lag 1 was lower (RR $1.007,95 \%$ CI 0.972 to 1.045 ). For $\mathrm{NO}_{2}$ the association was consistently greater at higher time exposures in Barcelona, London and Paris, and it was statistically significant overall. An increase in $50 \mu \mathrm{g} / \mathrm{m}^{3}$ of 24 hour average $\mathrm{NO}_{2}$ levels led to an increase of $2.9 \%$ ( $95 \%$ CI $0.3 \%$ to $5.5 \%$ ). Results for Helsinki were different, although not significantly so, from the other cities. The lags among cities were inconsistent, being either the same day or day 1 for daily average, and the previous day or day 3 for cumulative. However, the associations for lags 0 and 1 in all cities were very similar, the cumulative effect at lag 1 for all cities being 1.034 (95\% CI 1.009 to 1.060 ). For $\mathrm{O}_{3}$ local associations in Barcelona and London were positive and statistically significant, but significantly different from that in Paris $(\mathrm{p}<0.1)$.

The association for $\mathrm{NO}_{2}$ did not show a seasonal variation in the combined analysis (fig 1A) nor in individual cities in any of the time exposures assessed. Association with black

Table 3 Adjusted $\dagger$ relative risk of asthma admissions under age 15 per $50 \mu g / \mathrm{m}^{3}$ increase in air pollutants (and lag) ${ }^{12}$

\begin{tabular}{|c|c|c|c|c|}
\hline Air pollutant & Helsinki & London & Paris & Total $(95 \%$ CI) \\
\hline \multicolumn{5}{|l|}{ Sulphur dioxide } \\
\hline $24 \mathrm{~h}$ average & $0.791(0)$ & $1.089 * *(1)$ & $1.070 * *(2)$ & 1.075 (1.026 to 1.126$)^{*}$ \\
\hline Cumulative & 0.709 (3) & $1.113 *(2)$ & $1.022(2)$ & $1.061(0.996$ to 1.131$)$ \\
\hline \multicolumn{5}{|l|}{ Black smoke } \\
\hline $24 \mathrm{~h}$ average & - & $1.031(0)$ & $1.030(2)$ & $1.030(0.979$ to 1.084$)$ \\
\hline Cumulative & - & $1.046(3)$ & $1.046(2)$ & $1.046(0.978$ to 1.120$)$ \\
\hline \multicolumn{5}{|l|}{ Nitrogen dioxide } \\
\hline Hourly maximum & $0.958(0)$ & $1.011(2)$ & $1.008(1)$ & $1.011(0.999$ to 1.022$)$ \\
\hline $24 \mathrm{~h}$ average & $0.758(0)$ & $1.027 * *(2)$ & $1.026(2)$ & $1.026(1.006 \text { to } 1.049)^{* *}$ \\
\hline Cumulative & $0.903(1)$ & $1.034 *(3)$ & $1.062(3)$ & $1.037(1.004 \text { to } 1.067)^{*}$ \\
\hline \multicolumn{5}{|l|}{ Ozone } \\
\hline Hourly maximum & $1.352(1)$ & $1.009(1)$ & $0.920(2)$ & $1.006(0.976$ to 1.037$)$ \\
\hline 8 hour maximum & $1.235(1)$ & $1.011(2)$ & $0.957(1)$ & 0.989 (0.941 to 1.038$)$ \\
\hline
\end{tabular}

${ }^{1}$ Single day lag: effects may be on the same day (0) or lagged up to three days (3).

${ }^{2}$ Cumulative: effects of mean of same day and up to three previous days.

$* \mathrm{p}<0.05 ; * * \mathrm{p}<0.025$.

t Adjusted for trend, seasonality, day of the week, temperature, humidity, and influenza epidemics. smoke was higher during the winter (fig 1A), although the seasonal variation was not statistically significant $(\mathrm{p}>0.1)$. The seasonal variation in levels of black smoke was not consistent among cities - for example, in Barcelona the effect was stronger in the warm season while in London and Paris it was higher in the cold season - although none of these differences was statistically significant. For $\mathrm{O}_{3}$ a seasonal variation was not observed in the combined analysis, but the association was significantly higher during the warm season in London and lower in Barcelona and Paris. Finally, $\mathrm{SO}_{2}$ levels had no association with any season.

In children a positive association was observed for levels of $\mathrm{SO}_{2}$, black smoke, and $\mathrm{NO}_{2}$
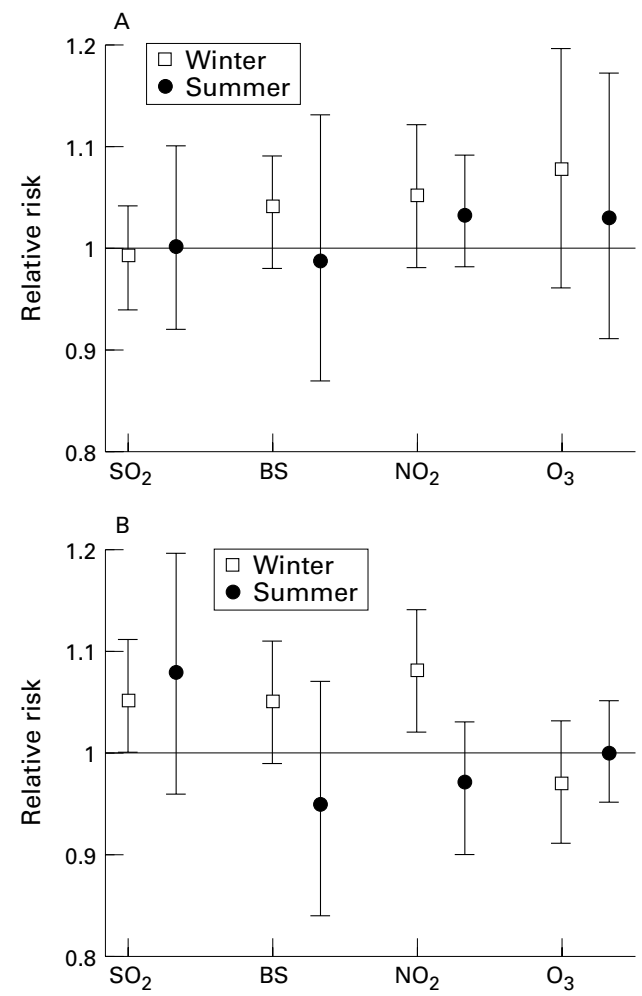

Figure 1 Seasonal variation of the adjusted relative risk per $50 \mu \mathrm{g} / \mathrm{m}^{3}$ (and 95\% confidence interval) of asthma admissions for $(A)$ subjects aged 15-64 years and $(B)$ children under the age of 15 years. $\mathrm{SO}_{2}=$ sulphur dioxide; $\mathrm{BS}=$ black smoke; $\mathrm{NO}_{2}=$ nitrogen dioxide; $\mathrm{O}_{3}=$ ozone. 
Table 4 Two-pollutant models: adjusted $\dagger$ relative risk of asthma admissions per $50 \mu \mathrm{g} / \mathrm{m}^{3}$ increase in air pollutants (and lag) ${ }^{12}$

\begin{tabular}{|c|c|c|c|c|c|}
\hline Age & Air pollutants & Barcelona & London & Paris & Total $(95 \%$ CI) \\
\hline \multicolumn{6}{|c|}{$15-64$} \\
\hline & $24 \mathrm{~h}$ average & & & & \\
\hline & Nitrogen dioxide & $1.039(0)^{1}$ & $1.086 *(0)$ & $1.055 *(1)$ & 1.055 (1.005 to 1.109$) *$ \\
\hline & Black smoke & $1.031(0)$ & $0.909 *(0)$ & $0.986(1)$ & $0.999(0.952$ to 1.049$)$ \\
\hline & Cumulative & & & & \\
\hline & Nitrogen dioxide & $1.044(3)^{2}$ & $1.104 *(1)$ & $1.112 *(1)$ & $1.088(1.025 \text { to } 1.155)^{*}$ \\
\hline & Black smoke & $1.076(3)$ & $0.881 *(1)$ & $0.965(1)$ & 0.991 (0.901 to 1.089$)$ \\
\hline \multirow{2}{*}{\multicolumn{6}{|c|}{$24 \mathrm{~h}$ average }} \\
\hline & $24 \mathrm{~h}$ average & & & & \\
\hline & Sulphur dioxide & - & $1.090 *(1)$ & $1.094(2)$ & 1.092 (1.031 to 1.156$)^{*}$ \\
\hline & Black smoke & - & $0.978(0)$ & $0.972(2)$ & $0.974(0.903$ to 1.050$)$ \\
\hline & Nitrogen dioxide & - & $1.065 *(2)$ & $0.975(2)$ & $1.036(0.956$ to 1.122$)$ \\
\hline & Black smoke & - & $1.013(0)$ & $1.058(2)$ & $1.037(0.965$ to 1.063$)$ \\
\hline & Sulphur dioxide & - & $1.063(1)$ & $1.092 *(2)$ & 1.075 (1.019 to 1.135$)^{*}$ \\
\hline & Nitrogen dioxide & - & $1.049 *(2)$ & $0.976(2)$ & $1.034(0.988$ to 1.082$)$ \\
\hline
\end{tabular}

${ }^{1}$ Single day lag: effects may be on the same day (0) or lagged up to three days (3).

${ }^{2}$ Cumulative: effects of mean of same day and up to three previous days.

$* \mathrm{p}<0.05$.

t Adjusted for trend, seasonality, day of the week, temperature, humidity, influenza epidemics, and the other pollutant in the model.

(table 3). In London and Paris very similar associations were seen for $\mathrm{SO}_{2}$, black smoke, and $\mathrm{NO}_{2}$, whereas in Helsinki there were contradictory results although the differences were not statistically significant. The combined association reflects mostly the findings for London and Paris, since Helsinki contributed to less than $1 \%$ of the total variance. The strongest association was found for the 24 hour average of $\mathrm{SO}_{2}$ (an increase of $50 \mu \mathrm{g} / \mathrm{m}^{3}$ in the 24 hour average $\mathrm{SO}_{2}$ level led to an increase of $7.5 \%$ (95\% CI 2.6 to 13$)$ ). This association did not vary with the seasons (fig 1B). The cumulative association was lower due to a different pattern of lags between London and Paris. As in adults, the association with black smoke was higher in winter, though the variation with the season was not statistically significant. The association for $\mathrm{NO}_{2}$ increased consistently with increasing exposure time, but it varied with the season $(\mathrm{p}$ $<0.1)$ being higher during the winter ( $R R$ $1.080,95 \%$ CI 1.025 to 1.140 ). No association was found with $\mathrm{O}_{3}$ levels in either the combined or individual city analyses, nor with any season.

To test if the associations for individual pollutants remained after adjustment for other pollutants, models including two pollutants were fitted (table 4). Adjustment for particles increased the association for $\mathrm{NO}_{2}$ in adults relative to the model with a single pollutant, both for a one day lag and for the cumulative lag; in this model there was a reduction in the association with black smoke. This occurred locally in London and Paris and in the combined analysis. Similar findings were observed in children for the association with $\mathrm{SO}_{2}$ levels. Adjustment of $\mathrm{NO}_{2}$ for black smoke or $\mathrm{SO}_{2}$ in children resulted in a different pattern between London and Paris. While in London the association with $\mathrm{NO}_{2}$ levels increased and that with black smoke or $\mathrm{SO}_{2}$ levels decreased, in Paris the pattern was the opposite.

\section{Discussion}

Most previous studies of health effects at low levels of air pollution have been carried out in the USA. ${ }^{10}$ This combined standardised ana- lysis of four European cities has extended to Europe evidence for an association between air pollution at current urban levels and admissions for asthma. Among the air pollutants the most consistent effects were found for particles and $\mathrm{NO}_{2}$ in individuals of all ages, and $\mathrm{SO}_{2}$ in children.

The combined analysis of cities with differing meteorological characteristics and pollution mixtures is an advantage for an analysis of pollutants with a common source in all cities, such as vehicle exhausts, since it allows a partial control of the environmental variables and their interactions and increases external validity. However, pollutants generated by interaction with local factors such as $\mathrm{O}_{3}$ may show a high degree of heterogeneity due to variations between cities in daily activity patterns of inhabitants, climate, or the location of monitoring sites that cannot be controlled for. In the case of $\mathrm{O}_{3}$, the low number of cities precluded the conduct of a weighted regression in order to adjust for city characteristics. For $\mathrm{NO}_{2}$ and $\mathrm{SO}_{2}$ Helsinki showed a discrepant association. The statistical model used by the APHEA might explain this inconsistency. The current statistical strategy has been shown to be a robust and sensitive method of removing seasonality in a standard way in a multi-city study compared with more sophisticated non-parametric techniques. ${ }^{24}$ However, the specification of the present regression models with a high number of parameters may have underestimated the association in Helsinki, ${ }^{14}$ a city with very few cases of asthma, since previous analyses in Helsinki using more parsimonious models resulted in positive and significant associations. ${ }^{2526}$

Current discussions of the implications of temporal/ecological findings suggest that problems due to misclassification in exposure could not explain the present results. ${ }^{11227} \mathrm{~A}$ major problem is the effect of confounding variables such as meteorological factors or unmeasured variables. Special effort has been made to control efficiently for humidity and temperature using centre-specific models. Among the unmeasured variables, pollen or other allergenic events could be responsible for part of the present association. However, the association observed in cold seasons, when grass pollen levels are low, precludes in part such a confounding. It is unlikely that indoor pollution from indoor sources confounds the present associations since day to day variations in indoor emissions are not correlated with outdoor air pollution.

The outcome variable is not strictly the same in all cities - emergency room visits in Barcelona, emergency hospital admissions in London and Helsinki, and total admissions in Paris - which creates problems of comparability and uniformity. A minor problem is that emergency admissions could not be separated from total admissions in Paris. On the basis of the analysis of the London data, it is likely that most of the asthma admissions in Paris were also emergency admissions. A potentially important problem is the inclusion of visits in Barcelona and admissions in the other cities. However, the consistency of results between Barcelona 
and London and Paris suggests that data could be aggregated.

The separation of the role of each pollutant is limited since we used an environmental measurement of exposure. A single pollutant could act as a marker of a pollution mixture. Hence, $\mathrm{NO}_{2}$ could be a marker of other pollutants generated by vehicle exhausts such as particles. We have tried to separate the independent effects of pollutants using two pollutant models. These models, however, are limited by the collinearity among pollutants generated by the same source - that is, the correlation between black smoke and $\mathrm{NO}_{2}$ ranged from 0.29 in Barcelona to 0.49 in London. Collinearity may explain the change of sign of the coefficient of black smoke in the two pollutant models. An alternative explanation is that associations with $\mathrm{NO}_{2}$ and $\mathrm{SO}_{2}$ are independent of particle levels. Further research is required on exposure to mixtures including $\mathrm{NO}_{2}, \mathrm{SO}_{2}$, and particles in volunteers in ambient air and in the laboratory.

Each centre selected the lag which gave the greatest effect instead of an a priori selected lag in order to allow for local variations in environment, health system and monitoring networks which might be associated with different lags. The selection of the best lag produced results which are difficult to interpret but have the advantage of incorporating local specificity. However, when combined coefficients were estimated for the same lag in all cities the findings were essentially the same.

The strategy followed increases the level of statistical error due to the high number of models explored. Although chance could explain the association observed for particles (black smoke) in all cities, the consistency of our findings with results from Seattle ${ }^{28}$ and Utah Valley ${ }^{29}$ in the USA suggests that this is unlikely. The association we observed is weaker than that in the US studies. This could be explained by the use of black smoke as the indicator of particles, since presumably the proportion of unmeasured biologically active non-black particles varies on a day-to-day basis. For $\mathrm{NO}_{2}$ and $\mathrm{SO}_{2}$ the associations observed are unlikely to be due to chance - that is, a statistically significant increased risk for $\mathrm{NO}_{2}$ was present in both age groups in all the cities except Helsinki in a consistent gradient according to the time of exposure and in both seasons in adults; the association for $\mathrm{SO}_{2}$ in children was highly significant - but only some of the previous population studies have reported similar associations. Only previous studies in Barcelona and Helsinki using the same data as in the current analysis but with a different methodology, ${ }^{1525}$ and a recent analysis in Birmingham, $\mathrm{UK}^{30}$ have reported an increase in the number of emergency room visits for asthma in relation to $\mathrm{NO}_{2}$ urban levels. For $\mathrm{SO}_{2}$ population studies did not show an association with asthma, ${ }^{2}$ although studies carried out during the 1960 s reported an increase in respiratory infections in relation to $\mathrm{SO}_{2}$ in children ${ }^{31}$ and in children with asthma. ${ }^{32}$ Ozone has previously been found to be associated with asthma visits in some locations such as
Southern Canada, ${ }^{33}$ but not in others such as the western coast of North America. ${ }^{28}$ Similarly, we did not find a consistent pattern among the European cities.

Explanations for the role of the density of respirable particles on asthma exacerbations have been suggested, ${ }^{2}$ but what is the plausibility that short term fluctuations in levels of $\mathrm{NO}_{2}$ or $\mathrm{SO}_{2}$ could be related to asthma attacks? In asthmatic volunteers, laboratory exposures to levels of $\mathrm{NO}_{2}$ compatible with those observed in our cities (hourly peaks of more than $400 \mu \mathrm{g} /$ $\mathrm{m}^{3}$ occurred in Paris and more than $700 \mu \mathrm{g} /$ $\mathrm{m}^{3}$ in Barcelona and London) increased nonspecific $^{3435}$ and allergen-specific ${ }^{78}$ bronchial responsiveness and produced some cellular damage. In panel studies of asthmatic subjects ambient levels of $\mathrm{NO}_{2}$ were related to a decrease in pulmonary function (peak flow). ${ }^{3637}$ This suggests that the observed association with ambient $\mathrm{NO}_{2}$ levels in the general population may be plausible. $\mathrm{SO}_{2}$ is a well known irritant ${ }^{3}$ which has been found in chamber studies to affect asthmatic subjects, but at levels higher than those observed in our cities. ${ }^{210}$ However, only adults have been challenged in chamber studies and we only observed an association with $\mathrm{SO}_{2}$ in children. In a general population panel study of children from six American cities an association between $\mathrm{SO}_{2}$ and lower respiratory symptoms was postulated to be due to a confounding effect of fine particles. ${ }^{38}$ We could not rule out this possibility which merits further investigation.

In summary, our results suggest a consistent impact of levels of particles and $\mathrm{NO}_{2}$ on asthma admissions and of $\mathrm{SO}_{2}$ levels on asthma admissions in children in the European cities. The associations observed were weak (a 3\% increase per $50 \mu \mathrm{g} / \mathrm{m}^{3} \mathrm{NO}_{2}$ ), though their impact could be important - for example, more than $50 \%$ of days in Barcelona and London were above $50 \mu \mathrm{g} / \mathrm{m}^{3}$. More controversial is the finding that associations of asthma with $\mathrm{O}_{3}$ levels varied with the cities and seasons, possibly due to a local variation in levels of this pollutant. This study reinforces the possible role of particles on asthma attacks, although they should be interpreted with caution because of a lack of statistical significance and results from the two-pollutant models. The results indicate that $\mathrm{NO}_{2}$, by itself or as a constituent of traffic exhaust fumes, may be important in exacerbations of asthma, and that current levels of $\mathrm{SO}_{2}$ may still be harmful to susceptible children.

The APHEA project was supported by the European Commission, DGXII, Environment 1991-94 programme (contract number EV5V CT92-0202, scientific responsible Dr C Nolan). The APHEA collaborative group consists of: K Katsouyanni, G Touloumi, E Samoli (Greece, Coordinating Center); D Zmirou, P Ritter, T Barumandzadeh, F Balducci, G Lam Zmirou, P Ritter, T Barumandzadeh, F Balducci, G Laham (Lyon, France); H E Wichmann, C Spix (Germany); J Sunyer J Castellsagué, M Saez, A Tobías (Spain); J P Schouten, J M Ronk, A C M de Graaf (Netherlands); A Ponkä (Finland); H $\mathrm{R}$ Anderson, A Ponce de León, R Atkinson, J Bower, D Strachan, M Bland (UK); W Dab, P Quenel, S Medina, A Le Tertre, B Thelot, B Festy, Y Le Moullec, C Monteil (Paris, France); B Wojtyniak, T Piekarski (Poland); M A Vigotti, G Rossi, L Bisanti, F Repetto, A Zanobetti (Italy); L Bacharova, K Fandakova (Slovakia).

1 Weiss KB, Gergen PJ, Wagener DK. Breathing better or wheezing worse? The changing epidemiology of asthm 
morbidity and mortality. Ann Rev Public Health 1993;14: 491-513.

2 Department of Health Advisory Group on the Medical Effects of Air Pollution Episodes. Asthma and outdoor air pollution. London: HMSO; 1995.

3 Sheppard D. Sulfur dioxide and asthma. A double-edged sword. 7 Allergy Clin Immunol 1988;82:961-4.

4 Molfino NA, Wright SC, Katz I, Tarlo S, Silverman F, McClean PA, et al. Effect of low concentrations of ozone on inhaled allergen responses in asthmatic subjects. Lancet 1991;338:199-203.

5 Devalia JL, Sapsford RJ, Cundell DR, Rusznak C, Campbell AM, Davies RJ. Human bronchial epithelial cell dysfunction following in vitro exposure to nitrogen dioxide. Eur Respir F 1993;6:1308-16.

6 Aris RM, Christian D, Hearne PQ, Finkbeiner WE, Balmes JR. Ozone-induced airway inflammation in humans subjects determined by airway lavage and biopsy. Am Rev Respir Dis 1993;148:1363-72.

7 Devalia JL, Rusznack C, Herdman MJ, Trigg CJ, Tarraf H, Davies RJ. Effect of nitrogen dioxide and sulphur dioxide on airway response of mild asthmatic patients to allergen inhalation. Lancet 1994;334:1688-71.

8 Tunnicliffe WS, Burge PS, Ayres JG. Effect of domestic concentrations of nitrogen dioxide on airway responses to inhaled allergen in asthmatic patients. Lancet 1994;344: 1733-6.

9 Jörres R, Nowak D, Magnusseen H. The effects of ozone exposure on allergen responsiveness in subjects with
asthma or rhinitis. Am $\mathcal{F}$ Respir Crit Care Med 1996;153: 56-64.

10 Bascom R, Bromberg PhA, Costa DA, Devlin R, Dockery DW, Frampton MW, et al. Health effects of outdoor air pollution. Am F Respir Crit Care Med 1996;153:3-55.

11 Susser MB. The logic in ecological: II. The logic of design. Am f Public Health 1994;84:830-5.

12 Haatch $M$, Thomas D. Measurement issues in environmental epidemiology. Environ Health Perspectives 1993;101:49-57S.

13 Katsouyanni K, Zmirou D, Spix C, Sunyer J, Shoutten JP, Ponka A, et al. Short term effects of air pollution on health: a European approach using epidemiologic time series data. The APHEA project: backg
design. Eur Respir f 1995;8:1030-8.

14 Ponka A, Virtanen M. Asthma and ambient air pollution in Helsinki. 7 Epidemiol Community Health 1996;50:s59-63.

15 Castellsagué J, Sunyer J, Sáez M, Antó JM. Shortterm association of urban air pollution with emergency room visits for asthma. Thorax 1995;50:1051-6.

16 Martinez F, Sunyer J, Antó JM. Reliability of a monitoring system for respiratory emergency room admissions. Eur Respir F 1993;6:337-41.

17 Ponce de León A, Anderson R, Bland JM, Strachan DP. The effects of air pollution on daily hospital admissions for respiratory diseases in London: 1987-88 to 1991-92. f Epidemiol Community Health 1996;50:s63-70.

18 Dab W, Medina S, Quénel P. Short-term respiratory health effects of ambient air pollution:results on the APHEA project in Paris. I Epidemiol Community Health 1996;50: s42-6.
19 Martinez FD, Wright AL, Halonen M, Morgan WJ. Asthma and wheezing in the first 6 years of life. $N$ Engl $\mathcal{F} M e d$ 1995;332:133-8.

20 Sunyer J, Castellsagué J, Sáez M, Tobías A, Antó JM. Air pollution and mortality in Barcelona. $\mathcal{F}$ Epidemiol Community Health 1996;50:s76-80.

21 Katsouyanni K, Schwartz J, Spix C, Zmirou D, Zanobett A, Woityniak B, et al. Shortterm effects of air pollution on health: a European approach using epidemiologic time series data: the APHEA protocol. I Epidemiol Community Health 1996;50:s12-18.

22 Schwartz J, Spix C, Touloumi G, Bacharova L, Barumandzadeh T, Le Tertre A, et al. Methodological issues of air pollution and daily counts of deaths or hospital admissions. F Epidemiol Community Health 1996;50:s3-11.

23 Dickerson K, Berlin JA. Meta-analysis: state of the science. Epidemiol Rev 1992;154-76.

24 Schwartz J. Air pollution and hospital admissions for the elderly in Birmingham, Alabama. Am $\mathcal{f}$ Respir Crit Care Med 1994;150:648-55.

25 Pönka A. Asthma and low level air pollution in Helsinki. Arch Environ Health 1991;46:262-70.

26 Rossi OV, Kimula VL. Association of severe asthma attacks with weather, pollen and air pollution. Thorax 1993;48: $244-8$

27 Schwartz J, Morris R. Air pollution and hospital admissions for cardiovascular disease in Detroit, Michigan. Am 7 Epidemiol 1995;1:23-35.

28 Schwartz J, Slater D, Larson TV, Pierson WE, Koenig JQ Particulate air pollution and hospital emergency room visits for asthma in Seattle. Am Rev Respir Dis 1993;147: 826-31.

29 Pope CA, Dockery DW, Spengler JD, Raizenne ME. Respiratory health and PM pollution. A daily time series analysis. Am Rev Respir Dis 1991;144:668-74.

30 Walters SM, Phupinyokul M, Ayres JG. Hospital admissions rates for asthma and respiratory diseases in West Midlands: their relationship to air pollution levels. Thorax 1995;50: 848-54.

31 Girsh L, Shubin E, Dick CH. A study on the epidemiology of asthma in children of Philadelphia. F Allergy 1967;39: $347-57$

32 Douglas JWB, Waller RE. Air pollution and respiratory infections in children. Br f Prev Soc Med 1966:20:1-8.

33 Bates DV, Sizto R. Air pollution and hospital admissions in southern Ontario: the acid summer haze effect. Environ Res 1987;43:317-31

34 Orehe J, Massari JP, Gayrard P, Grimaud C, Charpin J. Effect of short-term, low-level nitrogen exposure on bronchial sensitivity of asthmatic patients. F Clin Invest 1976; 57:301-7.

35 Folinsbee LJ. Does nitrogen dioxide exposure increase airways responsiveness? Toxicol Ind Health 1992;8:273-83.

36 Moseholm L, Taudorf E, Frosing A. Pulmonary function changes in asthmatics associated with low-level $\mathrm{SO}_{2}$ and $\mathrm{NO}_{2}$ air pollution, weather, and medicine intake. Allergy 1993;48:334-44.

37 Moseler M, Hendel-Kramer A, Karmaus W, Forster J, Weiss $\mathrm{K}$, Urbanek R, et al. Effects of moderate $\mathrm{NO}_{2}$ air pollution on lung function of children with asthma symptoms. Environ Res 1994;67:109-24.

38 Schwartz J, Dockery DW, Neas LM, Wypij D, Ware JH, Spengler JD, et al. Acute effects of summer air pollution on respiratory symptom reporting in children. Am Rev Respir Dis 1994;150:1234-42. 